\title{
THE TORRES STRAIT ISLANDERS AND THE PEARLING INDUSTRY: A CASE OF INTERNAL COLONIALISM*
}

\author{
Jeremy Beckett
}

The Torres Strait Islanders are Australia's Melanesian minority. Currently numbering some ten thousand, they are today found throughout the continent, but their homes are a score of islands that lie between Cape York and the southern coast of New Guinea. The Islanders' first known contacts with Europeans occurred early in the seventeenth century, but they did not have to come to terms with a permanent white presence until the middle of the nineteenth. This was not the catastrophe for them that it was for so many mainland Aborigines. The Europeans came mainly to exploit the region's marine resources, and so had no occasion to displace indigenous communities or encroach upon traditional means of livelihood. They did, however, need labour while Islanders wanted the goods which could be got by working. This exchange relationship provides the key to an understanding of postcontact Torres Strait society, and of that society's relationship with the rest of Australia.

Although meshed into the mainland economy for more than a century, Torres Strait has remained an enclave of underdevelopment with its own distinctive structure. ${ }^{1}$ This had been due less to geographical isolation or cultural backwardness than to the nature of the marine industry and the place of the Islanders in it. The industry, which is to say pearling and trepanging, has always been marginal, able to survive only through access to cheap labour. Lacking any alternative, Islanders have worked for small wages; but this they could only do as long as they could supplement their eamings with sea food and garden produce. They were thus anchored to their communities, which became part of the industry's support structure.

Torres Strait is part of Queensland, and the state government's 'native affairs' agency has been a powerful political force there. ${ }^{2}$ Until recently, however, its activities consisted largely of maintaining and regulating the arrangement just described, and the indigenous communities which lay back of it. In relation to the rest of Australia, the

* The writer first worked in Torres Strait from 1958 to 1961 as a Research Scholar of the Australian National University, returning in 1967 and 1976 with assistance from Sydney University. Paul Alexander, Delmos Jones, Bruce Kapferer, Bob Reece and Kerry Levis have helped at various stages in the writing of this paper.

1 The term underdevelopment can be taken here in the simple sense of the term, although it is used with Gunder Frank's writing in mind.

2The agency has gone under many names: the Chief Protector's Department; Aboriginals' Department; Sub-Department of Native Affairs; Department of Aboriginal and Islander Affairs, and now Department of Aboriginal and Islander Advancement. 
policy did perpetuate the Islanders' status as a distinct and culturally inferior minority and confined them to a little niche in the labour force where they neither competed nor combined with white workers.

Since the mid-1960s the marine industry has been in a depression from which it seems unlikely to recover. Meanwhile, a burgeoning mainland economy has drawn Islanders out of their isolation into the general labour force, while those left behind exist mainly on welfare payments and employment in government relief programs. Their plight is a familiar one throughout the world, and its social repercussions have been farreaching. This paper, however, will focus on the period when pearling was still the mainstay of Torres Strait.

Internal colonialism seems an appropriate way to characterize the history of Torres Strait; and indeed Rowley has already drawn comparisons between 'colonial Áustralia' and pre-independence New Guinea. ${ }^{3}$ But the notion has been applied to like situations elsewhere, in Central and South America, in South Africa and even in the British Issles, so that a general formulation is in order. ${ }^{4}$

Colonialism, whether internal or external, places two territories on a footing of inequality in terms of power, economic exchange and status. These three 'dimensions' are always inter-related, but in a variable way. The metropolitan government usually has responsibility for 'colonial administration', while the exploitation of labour and resources is usually the province of private commercial enterprise. Colonial government usually protects and facilitates these interests, but it would be naive to imagine that it exists only for this purpose. If colonialism is primarily an economic phenomenon, it does not follow that every colony will be run for profit; some may be run at a loss as part of a wider strategy. How far the metropolitan society participates in the making of colonial policy and shares in the fruits of economic exploitation, is another important set of variables. In terms of status, the metropolitan and colonial societies are ranked. The distinction is sharper when there is racial or ethnic difference, but is also apparent in attitudes towards the ne'er-do-wells and adventurers who become settlers, and their creole offspring. It may cut across emerging class divisions; however, colonial elites are not just the outcome of these two in tersecting principles, but of the whole colonial matrix.

It was the pre-capitalistic societies of the world that proved most vulnerable to expansionist capitalism, hence the common association of colonialism with ethnic or racial difference. Colonialism tends to incorporate such differences, but varies in its response to the indigenous mode of production, mainly according to whether it is oriented to the settlement of population, the extraction of natural resources or the exploitation of labour. Harold Wolpe, in a discussion of internal colonial-

3 Rowley 1971:1-26.

4 See, for example, Gonzalez Casanova 1965; Stavenhagen 1965; Hechter 1974.

78. 
ism in South Africa, shows how the 'normal' tendency of capitalism to destroy other modes of production may be checked by a counter tendency to preserve them when they can be harnessed to the industrial wagon. ${ }^{5}$ Thus, it is the Bantu homelands that provide for the reproduction of labour, supporting the women and children, and the men when they are not in employment; while industry supports only its actual workers. The South African government's apartheid policy, then, may be said to maintain the articulation of the two modes of production.

Hartwig has proposed that this model should be applied to Australia. ${ }^{6}$ But for Wolpe internal colonialism occurs when capitalism develops predominantly by means of its relationship with non-capitalistic modes of production. ${ }^{7}$ Certain Australian industries such as pearling and cattle raising have developed in this way, but the economy as a whole has not. Consequently, unless we regard Australian capitalism as monolithic, we cannot see government policy simply as a service for local industries without reference to other interest groups. In fact we know little about the processes through which Australia's policies towards its indigenous peoples have been formed. For much of the time the big interest groups and the electorate at large have been uninformed and largely unconcerned. Legislators have variously evinced racism, humanitarianism and combinations of the two; sometimes proccupied with the public purse, sometimes with Australia's standing in the international arena. The cattlemen and pearlers have had their lobbies, but they have often found it easier to modify policy by applying pressure at the local level. Career administrators, mediating between the parties and often the best informed, have been a major influence. Queensland, particularly, has been noted for its forceful administrators, one of whom, J. W. Bleakley, was called to advise other Australian governments during the 1930s.

In all the discussion of internal colonialism little has been said about its implications for the development of a proletariat. Tribesmen and peasants do not immediately embrace the routines, rigours and scaled incentives of the industrial world: their tendency to withdraw when their immediate needs are met is notorious. Glossing Marx, Taussig writes:

the transition to the capitalist mode of production is only completed when direct force and external economic conditions, although still used, are only employed exceptionally. An entirely new set of conditions and habits have to be developed among the working class, to

5 Wolpe 1975.

6 Hartwig 1976.

7 Wolpe 1975:244. In a footnote $(1975: 252)$ he writes:

I leave open whether the notion of 'internal colonialism' has any proper application in conditions of racial discrimination where, however, the internal relations within the society are overwhelmingly capitalist in nature, that is, where non-capitalist modes of production, if they exist at all, are marginal.

This is the issue taken up in Hartwig 1976. 
the point where common sense regards the new conditions as natural. ${ }^{8}$ This conversion process must to some degree be inhibited under internal colonialism, for the individual has repeatedly to choose between wage labour and subsistence production; between use and exchange value.

The account that follows will be organized around the articulation of the subsistence and capitalistic modes of production in Torres Strait, and the role of government in regulating this arrangement. I shall be looking at the region as a whole, with its seventeen indigenous communities centred on the commercial and administrative settlement at Thursday Island (see map); but focusing on one community, Badu, which more than any other committed itself to the pearling industry.

Sydney-based trepang boats were reported in Torres Strait as early as $1846,{ }^{9}$ but from $1868^{10}$ until recently pearl-shell has been the staple of the industry, with golden-lip mother-of-pearl and trochus as the most important varieties. ${ }^{11}$ Both have been luxury products for alluring but fickle overseas markets. Trepang, otherwise known as bêche-de-mer, went as a culinary delicacy to the Chinese market, which closed at the outbreak of war in the Far East. Pearl shell, used mainly for ornaments and buttons, has had a worldwide market, which however has been controlled by a few big dealers, first in London and later in New York. Though organized in an association, the Torres Strait master pearlers have had no control over prices, and so have been subject to market manipulations as well as the vagaries of fashion. They have also been limited in their capacity to expand by the availability of shell: one year's overfishing resulting in shortage for several years after. Bach, the historian of the industry, wrote in its last phase, 'The economy of the industry is precarious, with a record of recurrent financial crises over the last forty years'. ${ }^{12}$ Pearling has had its prosperous times, but the reward for capital and labour has always been uncertain.

Enterprises ranged from small, locally based operators to well known metropolitan firms such as Burns Philp. Any tendency toward consolidation was offset by the excessive efficiency of large concerns - resulting in overfishing - and on the other hand the ease with which a small operator could start up. Just enough capital was needed to buy, fit out and provision a sail boat, usually a lugger or cutter, big enough to

8 Taussig 1977:133. Taussig's brilliant analysis of the proletarianization of a group of Colombian peasants provides some basic insights in to the Torres Strait situation which $I$ hope to take up in a later publication.

9 MacGillivray 1852:308.

10 Captain Banner established a pearl shell station on Warrior Island in 1868 which seems to have been the first in the Strait.

11 Black lip mother-of-pearl and green snail shell have also been taken at times. Pearls provided a welcome bonus, but they occurred too irregularly and unpredictably to provide a basis for the industry.

12 Bach 1961:107.

80. 


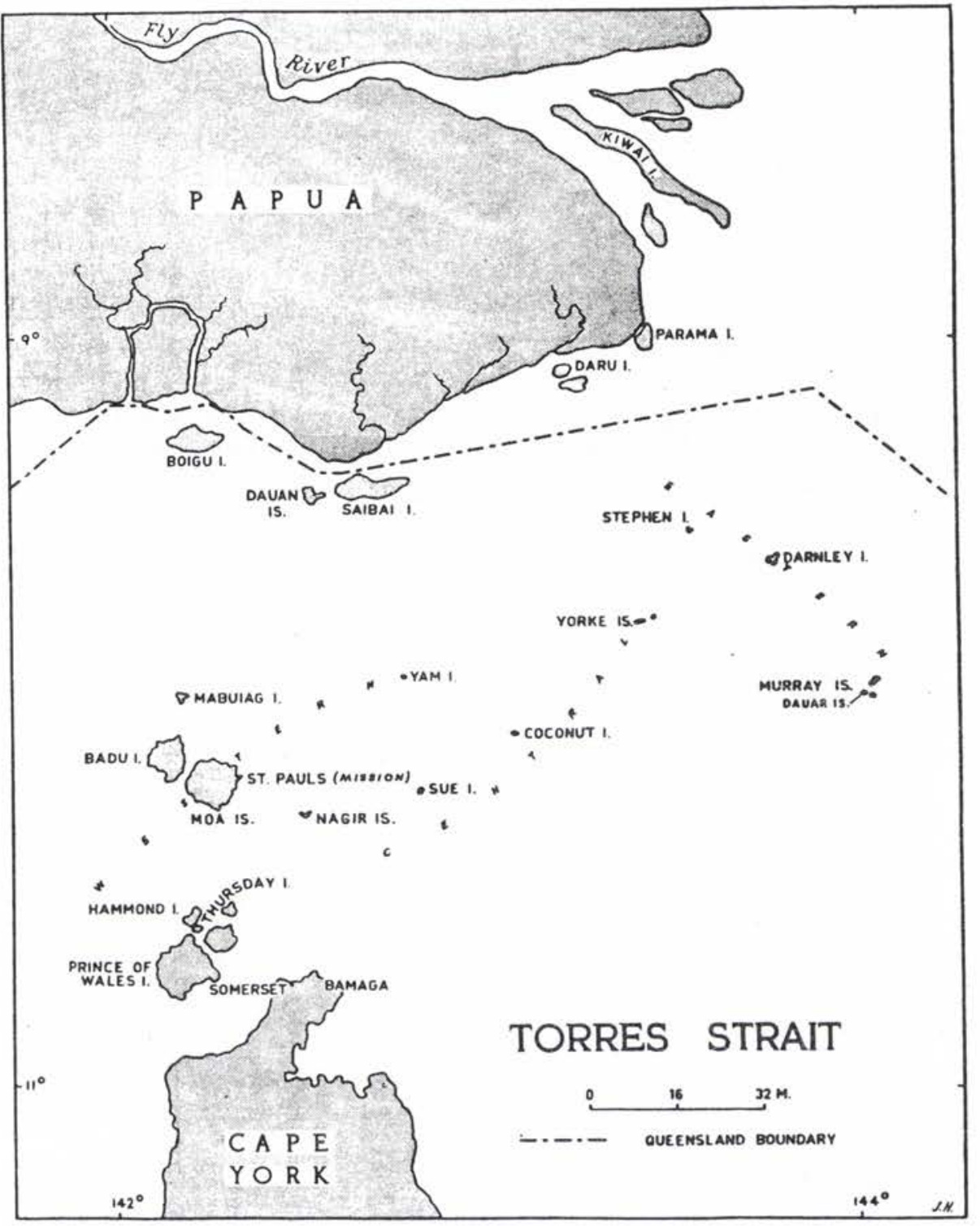

The Torres Strait Islands.

81. 
accommodate ten to twenty men. Diving equipment was needed for gold-lip, which was mostly below seven fathoms, beyond the reach of skin divers. Trepang and trochus were found at lesser depths, and all that one needed was a few dinghies to carry the divers from the lugger to the reef. In short, pearling and trepanging were labour intensive industries, with wages the major cost and the critical factor in determining profit margins. The recruitment and organization of labour were thus of paramount importance.

Veterans of the industry, white and black, all insist that the skipper's ability was critical: 'Better a good skipper with a bad crew than a bad skipper with a good crew'. He had to be familiar with tides, currents and winds, and to know where the fish was most abundant and most easily got. He needed also to be able to keep up the pace of work for weeks at a stretch; to reduce tensions among polyglot crews living under cramped noisome conditions; and to keep in check the resentments of men who, particularly in the early days, had been subject to gross abuse. ${ }^{13}$

The owners of the boats rarely took charge themselves. They preferred to avoid the squalid conditions, the poor diet and the weeks of monotony; still more the dangerous and debilitating deep water diving. Fortunately the masters could find able and reliable skippers at relatively low cost. In the 1870 s, when the price of shell was still high, whites were attracted to the work in which a skipper-diver could make as much as $£ 500$ in a year. ${ }^{14}$ But as shell became scarcer and prices fell, employers looked to Asia and the Pacific Islands for workers ready to accept less money. The skippers and divers of the 1880 s were Rotumans and New Caledonians, Malays and Manilamen until in the $1890 \mathrm{~s}$ the Japanese arrived, ready to undercut and outwork them all. In 1907, in the wake of the White Australia legislation, a Royal Commission investigated the feasibility of replacing alien workers with Europeans, as had been done in the sugar industry. ${ }^{15}$ But it was clear that no white man who could earn $£ 8$ a month as a coastal seaman would risk life and health for $£ 8.17$, which was the going rate for a diver. ${ }^{16}$ The masters in-

13 In the early years the Pacific Islanders had often been blackbirded, while Aborigines were shanghaied in to the present century. For an account of labour abuse in Torres Strait, see Evans 1972.

14 Somerset Magistrates' Letter Book, 3 April 1875.

15 Report of the Royal Commission ... 1908:1xi.

16 1908: lxiv. A report of the Northern Australia Development Committee, published in 1946, observed that:

For many years, pearl shell fishing was a most hazardous occupation. One of the risks to which the whole crew was exposed was that of beri-beri, owing to the necessity for using preserved food with no fresh fruit or vegetables; another common hazard among the divers was that of divers' paralysis, a result of too rapid changes of pressure. Many men died of these diseases. The rough and ready life also took its toll. Living quarters were cramped and uncomfortable, the life was utterly monotonous, there was little provision for living while on shore. It was taken for granted that luggers' crews usually

82. 
sisted they could not pay more and the Queensland government did not take up the Commission's proposal for a subsidy. ${ }^{17}$ As a result, the Torres Strait pearlers and trepangers, along with their colleagues in Western Australia and Darwin, remained exempt from the provisions of the White Australia policy right up to the outbreak of war with Japan. They were not allowed to resume when the war ended; but the labour, though local, was still cheap and coloured. It was Islanders who now filled the gap, not white men.

The 1907 Commission recognized that if white men could not be got to work as skipper-divers, there was no way that they would work as deck hands and skin divers at the going rate of $£ 1$ to $£ 2$ per month. These jobs could be given to Islanders, Aborigines and Papuans who, it allowed, had 'natural rights to employment', as well as being tractable. ${ }^{18}$ The first boats to work in Torres Strait had come already manned by Pacific Islanders; other 'Kanakas' made their own way up from the Queensland cane fields, and even from Sydney. ${ }^{19}$ But an industry liable to sudden booms needed to be able to expand its labour force at short notice. The indigenous populations of the region could be made into a convenient labour reserve if they could be broken in. At first they proved unwilling to work for prolonged periods, and if kidnapped tended either to abscond or to succumb to exotic diseases. But with time they acquired immunity and became inured to remaining at sea for months on end. Moreover they could be paid less than the more sophisticated Asians and Pacific Islanders. From the beginning of the century up to the outbreak of war in 1941 they made up more than half of the industry's labour force, with the Islanders constituting around 20 per cent.

Whether foreign or local, the workers were supported only while they were working, and there was little for their wives and children, still less for the communities from which they were recruited. In other words, the reproduction of labour was left to the subsistence economies of Torres Strait and of the countries of Asia and the South Pacific, which thus became subordinated to the marine industry.

The Torres Strait marine industry did not become a basis for any kind of diversification. There being few other exploitable resources, profits were either ploughed back or invested in more promising fields

spent the last days of their lives as physical wrecks.

The report adds there was now more skill in the treatment of the bends, although fatalities still occurred from time to time.

17 1908:lxiv.

18 1908: Ixix.

19 The Somerset Magistrates' Letter Book for 1872-1877 contains a number of references to crews recruited in various parts of the Pacific. From these sources and from the recollections of the descendants of Pacific Islanders born in Torres Strait, it seems that the majority came from Rotuma, Samoa and Niue, and from various islands in the Solomon and New Hebrides groups. 
elsewhere..$^{20}$ The industry may be said to have carried Torres Strait to the threshold of the Australian economy and then left it there. After the initial developments of the 1870 s and 1880 s it could neither expand nor diversify. Even this stunted development depended on continuing supplies of cheap labour. The labour supply itself depended on the backup support of subsistence economies; and once foreign labour was excluded the indigenous communities were largely responsible for the organization of labour as well.

On the eve of colonization, around the middle of last century, there were between three thousand and four thousand Islanders distributed over twenty islands. ${ }^{21}$ They lived by hunting turtle and dugong, by fishing, and either gathering or cultivating vegetable foods. The relative importance of these activities varied from one zone to another. In the western islands men busied themselves with hunting the great sea mammals, while the women fished and gathered wild roots and berries; there was little or no gardening. By contrast, the small, fertile, densely populated eastern islands rarely saw dugong and got their turtle mostly during one season. Both men and women devoted themselves to gardening and some fishing. The tiny Central Islands provided little vegetable food, either wild or cultivated; their inhabitants spent their time catching turtle and fish, part of which they traded with the cultivating peoples to the east.

Social organization was broadly the same throughout the islands and neighbouring New Guinea. Social relations were phrased in the idiom of kinship, with a patrilineal emphasis in the recruitment of residential and ritual groups. Economic activities dispersed and fragmented society. In the eastern islands men gardened with their wives and unmarried daughters, or alone. Elsewhere women gathered wild foods and caught fish alone or in small groups. Some co-operation was required to handle the big canoes that were used for hunting and trading, but the number never exceeded ten. This tendency to dispersal was offset by a rich ritual life that periodically brought together the people of one, and sometimes several, communities.

Pearlers and trepangers were the first foreigners to gain a foothold in the islands. They found the Islanders eager for trade goods such as iron tools and cloth, and ready to work at least for short periods to get them.

20 During the early years of the century several coconut plantations were established, but there seems to have been little or no copra production. For a few years after the second world war wolfram was mined on Moa Island. Otherwise the only resource has been fish, which to date has been exploited only on a small scale. For an analysis of the Torres Strait economy and its prospects, see Treadgold 1974.

21 This assessment, based on a number of sources, is discussed in Beckett 1972, which summarises the available data on indigenous Torres Strait. The primary source is the six-volume work edited by Haddon (1904-1935). 
But if workers were unwilling they were sometimes kidnapped, as were women to serve as prostitutes on the boats. Attempts at resistance only served to demonstrate the foreigners' superiority, so that when the London Missionary Society arrived in 1871 it met little opposition, and may have been welcomed as a protection against the rest. ${ }^{22}$ Within a decade the Society had won the adherence of the majority of Islanders, and begun the work of turning them into black replicas of the Victorian 'respectable working class'. ${ }^{23}$ The Queensland government had completed its annexation of the islands by 1879 , but lacking the means of administering them it was content to leave the missionaries to guide the 'chiefs' it had appointed.

The missionaries regarded most of the pearlers and trepangers as a 'bad influence', and would probably have preferred not to let their flocks stray out of their sight; but they could scarcely stifle the demand for trade goods, and indeed money was required to support the life style they were introducing. Before long they were encouraging communities to compete in the generosity of their donations to the mission, and in church building. Most of this money came from the wages of the young, unmarried men, who were most in demand with employers and most easily spared from their communities, being otherwise unproductive and a potent threat to sexual morality. The young men had their own incentive. Foreign workers in search of local wives had introduced marriage payments in the form of cash and manufactured goods: Islanders had to match them or miss out. ${ }^{24}$

It was, then, the young men who signed on for the boats, spending ten months of the year away from home, while their fathers stayed back to guard the morals of their wives and advance themselves in the mission hierarchy. Combining their traditional authority as parents with their new authority as church leaders, they effectively nullified the young men's economic importance and succeeded in controlling most of the money that they brought back. Having right of veto over marriage, they delayed the event so that they could enjoy the work of their sons a little longer and hold out for a good price for their daughters.

The older, married men continued in subsistence production, gardening and fishing in the company of their wives and daughters, and hunting with their age mates. However, towards the end of the nineteenth century they were buying small boats and working neighbouring reefs for shell or trepang. This seems to have reflected the growing demand for cash goods, including flour and rice, but did not amount to a complete abandonment of the subsistence production. Fish, dugong and turtle could still be caught on the way back from the working grounds. Not surprisingly, this arrangement proved more attractive to the hunt-

22 London Missionary Society, Reports, September 1876.

23 For an account of the L.M.S. in Torres Strait see Beckett n.d.

24 Haddon 1908:115. 
ing peoples of western and central Torres Strait, than to the horticulturalists of the east.

The one difficulty with this arrangement was that it failed to provide for the 'hungry time' during the Nor'west monsoon. The climatic conditions that caused a dearth of wild and cultivated vegetable foods, and made hunting and fishing difficult, also brought commercial fishing to a standstill. Flour, rice and canned goods could tide the people over, but money often ran out before the end of the season. Per capita cash income was still low and there were other calls on it, to support the church, to finance ceremonial feasts and marriage payments. Clearly, then, more effort must be put into commercial production.

To meet the problem, two missionaries formed a non-profit making company, Papuan Industries, in $1904 .{ }^{25}$ Its beginnings are described as follows:

... Revd. F. W. Walker, preaching at one of their church services, had reproached the Islanders for their apparent indolence. He pointed out the great wealth of marine produce at their very doors, the proceeds of which, if collected, would provide for the seasonal "hungry times". He was afterwards approached by a deputation of the people who explained that they had no money with which to buy fishing boats large enough to work profitably. ${ }^{26}$

For the next twenty-five years Papuan Industries loaned Islanders the money to buy boats, selling their produce and marketing trade goods at fair prices. After a few years the Queensland government went into partnership, taking over the company when its founders retired in 1930. Long before this date, it had taken effective control of what came to be called the 'company boats'.

The Queensland government's intervention was on too small a scale to threaten the masters, but still served to consolidate its hold over the Islanders. It seems to have been prompted by bureaucratic considerations, and as part of a statewide program for 'natives'. By 1890 the government had acquired the means for administering the islands, and began posting teacher-magistrates in the larger communities. This precipitated a struggle with the L.M.S. theocracy, which ended with the missionaries' withdrawal in 1914. The virtual take-over of Papuan Industries may have been one more move to reduce mission influence, but it was also in keeping with statewide policy. An Aborigines Protection Act had been passed in 1897, but the Hon. John Douglas, who had been Government Resident since 1886, believed that the Islanders were

25 The 1897 Queensland Parliamentary Commission report indicates that Walker was helping Islanders to buy before the establishment of Papuan Industries. However, the L.M.S. would not allow its missionaries to engage in trade. Walker was obliged to resign his position, but stayed on after the L.M.S. withdrew in 1915. L.M.S. Correspondence, 13 September 1896; see also Austin 1972.

26 Bleakley 1961:265.

86. 
superior to Aborigines and not in need of it. ${ }^{27}$ However, when he died in 1904, the incoming Chief Protector had them declared Aborigines for the purposes of the act. ${ }^{28}$

The White Australia agitation was at its height during these years, and working class fear of cheap labour was being expressed in terms of virulent racism. ${ }^{29}$ The Aborigines were scarcely a labour threat, but they were included in the general opprobrium, as an offence to white sensibility and morality. They could not be deported, like the Kanakas and Chinese, but they could be kept out of the way, 'for their own good' as well as that of the white majority. From this emerged a policy of protective segregation, whereby Aborigines would be confined on settlements and have as little outside contact as possible. The practice might better be described as arrested segregation, for there was never enough money to institutionalize everyone. Nor could the settlements be made self sufficient, so that it was necessary to hire out the best workers to pastoralists who, in any case, needed their labour. Since the government would have to provide if the worker was not paid or if he squandered his earnings, it had its own reasons for supervising employment and holding Aboriginal earnings. Under the tight controls that emerged, the government did not so much teach the Aborigines thrift as practice it on their behalf.

Islanders came under this regime after 1904. The commercial and administrative settlement on Thursday Island could not be rid of the Japanese, but Islanders and Aborigines were to be kept out as much as possible, and the surviving Pacific Islanders to be settled elsewhere. The Torres Strait communities were to be made self-supporting, with the aid of the company boat system, but the masters were to be allowed to hire the best workers under government supervision.

It is hard to tell how far indigenous entrepreneurship would have gone if the government had not taken over. Communities or community segments, called tribes, now worked off the price of the boats and became nominal owners; but the protector, having legal rights of disposal over native property, could do with boats and produce as he saw fit. In reality, then, the means of production were in white hands, and if there was no master to skim away profits, there was the protector instead deducting large sums for various funds and contingencies.

The company boats became a continuing source of conflict between government and Islanders, who made the mistake of believing that, once paid off, the boats were theirs to use as they pleased; and when told otherwise gave up in disgust. Again, while it was understood that the boats could be used for hunting they did not always get enough

27 Douglas 1899; Chief Protector of Aborigines' Report for 1904.

28 Queensland Parliamentary Debates 1938:408.

29 The best account of this period is to be found in Evans, Saunders and Cronin 1975. 
shell or trepang to cover running costs. The teacher-magistrates had to use stern sanctions before they could get the Islanders into line, and the Eastern Islanders, who had their fertile gardens to fall back on, remained refractory..$^{30}$

The government nevertheless persisted with the scheme, expanding its fleet to take advantage of the post-war boom, and persuading the men to divert their efforts from trepang and mother-of-pearl to trochus shell, which currently commanded a good price. In 1924, twenty-eight boats earned more than $£ 20,000$; and with wages on the master's boat raised to between $£ 3$ and $£ 4.10$ a month, the communities were fully self supporting, if not well to do. ${ }^{31}$ The number at work also increased, from 358 in 1921 , when the population was about three thousand, to 587 in 1923; and it continued upwards through the 1930s. This was partly due to population increase, but mainly due to the expansion of the company boat fleet, giving employment to the older married men and the less fit.

The relative prosperity of the 1920 s, during which Islanders increased their dependence on store commodities, came to an abrupt end with the great depression of 1930. The masters retrenched; the company boats worked on, but average per capita earnings for the year totalled only $\mathrm{f} 8$. The resentment that this aroused was not soothed by improving prices, and in 1936 the Islanders went on strike for four months. ${ }^{32}$ The private sector of the industry was unaffected. The grievances seem to have been various. The Chief Protector of the time supposed that the men wanted to handle their own money. ${ }^{33}$ Veterans of the strike cite the wretched pay, and the seeming lack of correspondence between effort and reward. Evidently officials did not bother to explain the complex system of deductions for debts incurred in earlier years, current running costs, and various community and contingency funds. Some workers simply supposed that they were being robbed..$^{34}$ On the masters' boats they were assured of a minimum wage, and earnings were generally higher. This was partly because the masters took only the best workers, but the unfavourable comparison remained.

The government was able to bring the Islanders into line with a show of force, but knew it would face trouble again before long if earnings did not improve. The only solution was to increase productivity, and the only way of doing this was to build up a cadre of skippers who

30 Chief Protector of Aborigines, Report for 1910:20; 1914:12.

31 Aboriginals' Department, Reports for 1925 et seq.

32 Aboriginals' Department, Reports for 1935-36.

33 Bleakley 1961:270.

34 This was alleged in the Communist press, which took up the Islanders' cause (Workers Weekly, 21 January and 21 February 1936). The Brisbane Telegraph of 8 January 1936 reports a statement of the responsible Minister to the effect that the Islanders 'were contributing something towards the support of Aboriginals on the Mainland'. Just what they were contributing and how was never made clear. 
could step up the old, easy-going pace of work.

The Islanders had produced little in the way of leadership up to this point. Authority had not been much developed in the traditional society, and what there was had disappeared during the missionary reconstruction. The church leaders confined themselves to parish matters, and the local government councillors, who had replaced the old chiefs, were overshadowed by the government teacher-magistrates. As in other parts of Melanesia, ambitious individuals strove to aggrandize themselves only to be cut down by an egalitarianism that had been reinforced by the Islanders' lowly position in the colonial order. ${ }^{35}$ The old style company boat skippers were at most primus inter pares, elected by community or crew, and regularly replaced, perhaps 'to give someone else a chance', perhaps because they had antagonized the men. Many chose not to take the slightly larger share of the boat's earnings to which the system entitled them. Discussing such matters in later years, Islanders all agree that a boat could not do well when 'everyone boss'. In that case, it worked at the pace of the slowest worker, arriving late at the working grounds and coming back early, on one pretext or another. To work boat and crew at full capacity, and to get ahead of running costs, a 'tough skipper' was needed.

During the 1920s a few 'tough skippers' had emerged, mainly from among the half-caste descendants of Pacific Island seamen, but their authority was personal. Only in Badu, in western Torres Strait, did the skipper's authority become institutionalized, largely due to the achievement of Tanu Nona.

Tanu Nona was born in Saibai Island in 1900, the son of a Saibai woman and a Samoan seaman. His parents settled on Badu soon after and there he was raised along with his seven brothers and three sisters. He began with no particular advantages. His father was evidently a stern man and ambitious for his sons, but without wealth or influence. Tanu had to make his own way and, according to his own account, lost no time in doing so. ${ }^{36}$

I got my first boat from Mr Luffman [a master pearler] in 1918. Then when I was nineteen I got the Coral Sea. I was going up to New Guinea to work out from Samarai, but my mother wanted me to stop and I took over as skipper of the island cutter, I've been a skipper ever since. Later the Poid people [a neighbouring community] made me captain of their lugger, the Manu. The government set me to race [i.e., compete] with Douglas Pitt from Darnley Island. In six weeks I got ten ton of trochus; Douglas Pitt only got five. That's how Badu got the Wakaid, the biggest lugger in Torres Strait. For six years we kept the cup [awarded by the government for the winning boat], until the competition was cancelled.

35 For a discussion of Torres Strait egalitarianism see Beckett 1972.

$36 \mathrm{I}$ conducted two long interviews with Mr Tanu Nona in 1959. 
The Wakaid's success was not easily won.

We stayed out sometimes for ten months on the coast, from Cape York to Gladstone [i.e., along the North Queensland coast]. You must have a strong captain to make those boys work. If they not get much shell I not let them into the dinghy to eat dinner, midday. They got to eat their piece of damper [bread] standing on the reef. Some skippers work only half day, six in the moming till dinner time, then sail onto the next reef. That way they lose half a day. But I keep them there till six in the evening. We cook the shell and sail on to the next reef night-time. Making the crew work is the main thing. Also knowing the tides. But you must make those boys finish the reef. Bad skippers leave some shell behind.

The government was quick to recognize Tanu's ability and to advance him. The competition, designed to take advantage of inter-island rivalries, probably strengthened his hold over the crew, and, when he won, enhanced his reputation. The Wakaid would have been an added source of pride and, because of its size, an asset in subsequent competitions. Nevertheless, the success was essentially Tanu's and he is the one credited with 'teaching Badu to work'. No doubt his forceful, not to say aggressive, personality was an important factor in transforming the old easy-going routine, but he was also able to take advantage of an unusual circumstance within the community. Towards the end of the 1920 s the community resolved to replace its decaying wooden church with a cement building. Tanu, already elected a local government councillor, now became a church-warden and director of the project. He began by decreeing that every able-bodied man should work full-time on the boats, giving up a portion of his earnings for the project. He next overrode the rule that a man might only work on the boat belonging to his tribe, henceforth taking into his crew the best workers whatever their affiliation:

I thought it silly that a good man couldn't work with others because he didn't belong to their tribe, and might have to work with other men who were no good. That was how Wakaid got all the best men.

With the benefit of hindsight we can regard these minor innovations as the opening moves in a process that was to transform Badu and have important implications for other communities. However, it is unlikely that even Tanu could see so far ahead. In the meantime the innovations could be justified in terms of established community values, principally the erection of a handsome new church that rivalled the Thursday Island cathedral for size. If the young men came home with more money than ever before, their mothers and fathers and the church leaders were the main beneficiaries. Tanu, then, remained a community as well as an economic leader, with wide popular support.

As is often the case with innovators, Tanu's relationship to the com- 
A CASE OF INTERNAL COLONIALISM
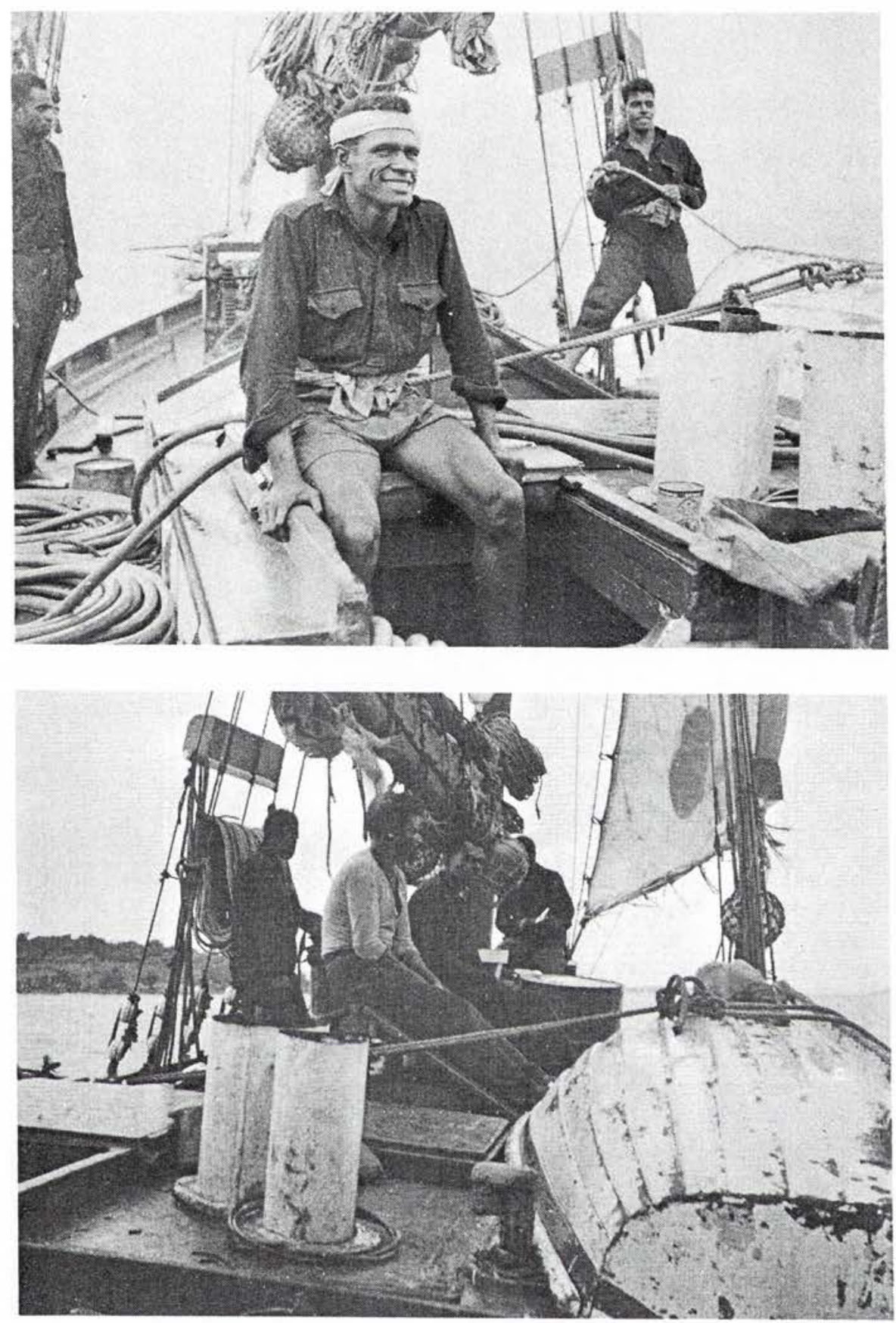

Top: Crew member, Nona pearling lugger, Badu, 1959.

Bottom: Nona pearling lugger, Badu, 1959. Photographs by Jeremy Beckett. 

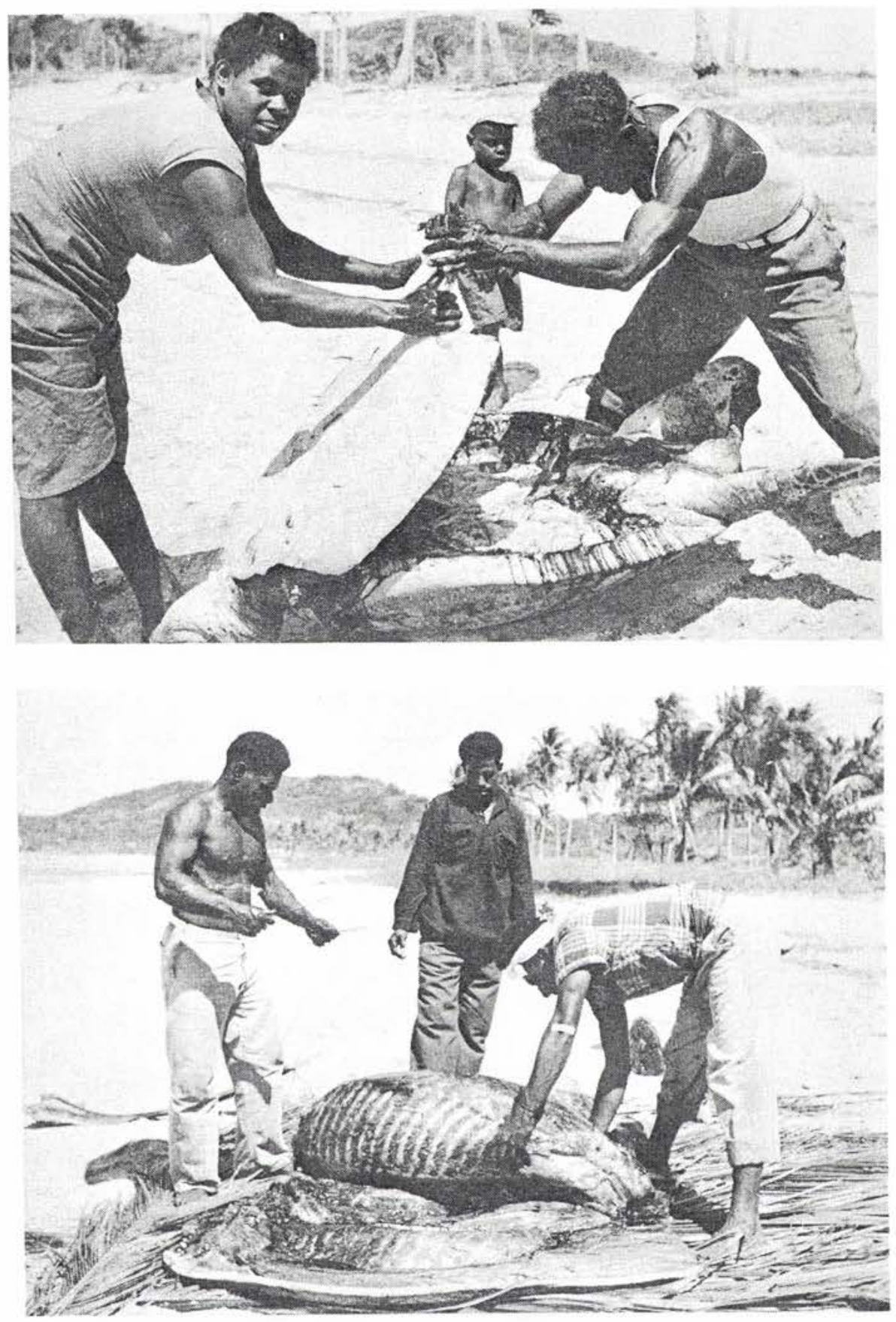

Top: Opening up a turtle, Badu.

Bottom: Butchering a dugong, Badu.

Photographs by Jeremy Beckett. 
munity was ambiguous. ${ }^{37}$ Though Badu bred he was not Badu born, and while he had acquired fictive kin and affines there he had no true kin. Again, as a 'South Sea half caste', he could lay some claim to superiority over 'Torres Strait natives' in terms of the prevailing ethnic stratification. ${ }^{38}$ Finally, while nominally an appointee of the community, he was developing an unusually close relationship with the government, which was rumoured to pay him a secret retainer over and above his skipper's share. This relationship was strengthened by his refusal to join the 1936 strike, and his subsequent reward, the Wakaid, now to be worked as a family boat.

Normal life was interrupted in 1941 with the outbreak of war in the Pacific. Torres Strait became a field of military operations, though not of hostilities, and almost every able-bodied Islander served alongside white soldiers as members of a special volunteer contingent. Their contacts with the white troops were a radical departure from what they had known hitherto. At the outbreak of war they had been more cut off from the rest of Australia than they were at the turn of the century, their only contacts being with whites who were in authority over them. They now found themselves included in a new camaraderie and hearing ideas which challenged what they had learned in church and schoolroom. Having served 'King and country', they thought they would be entitled to the 'new deal' promised Australian servicemen when the war ended. The Islanders supposed this would mean 'freedom': the end of government supervision and segregation, and 'full pay'. As one veteran explained to me, years later, 'We all came out of the army with swelled heads'.

In the new climate, the Queensland government found it difficult to restore the pre-war regime. ${ }^{39}$ However, boom conditions in the pearling industry, following four years of inactivity, eased its task and enabled it to offer certain concessions without making any structural change. Taking advantage of the Australia-wide anti-Japanese feeling, the government insisted that the Islanders could and should provide the industry with all its manpower, including skippers and divers as well as crew.40 It also negotiated a new wage agreement which brought the basic rate to a little over 50 per cent of the national basic wage, with bonus incentives, and higher rates for divers and skippers. The latter could now hope to earn as much as white workers.

37 See Press 1969.

38 Pacific Islanders married to local women were allowed to remain after their fellows had been deported. However, they were faced with the choice of becoming Aborigines under the terms of the Act, or removing to the St Pauls or

Hammond Island missions where conditions were much the same as on the reserves. Their status nevertheless remained anomalous, and after 1945 their half-caste descendants were allowed to vote, take alcohol and travel as they pleased. These rights were still denied to half-castes living on the reserves.

39 Sub-Department of Native Affairs, Reports for 1946-47. 
The government had been negotiating wage agreements with the masters since 1904 , as part of its statutory control over native employment. In 1907 Protector Costin had suggested that the Islanders were 'worth' $£ 2$ a month, though 'of course they have very inflated ideas of their own value'. ${ }^{41}$ In fact, he was going along with established practice whch rated Islanders below Asians and Kanakas, but above Papuans and Aborigines. His successors arranged increases from time to time, sometimes in response to shifts in living costs, sometimes in response to fluctuations in the industry. The employers, of course, insisted that increases were beyond their ability to pay, and more than the Islanders were 'worth'. But while these assertions can be taken with a grain of salt, it must also be recognized that the industry was predicated upon cheap labour, and had to compete with cheap labour producers such as the Philippines and the Cook Islands.

The gains made in the post-war boom years were soon swallowed up by inflation, and though the rates increased from time to time, there was a decline in real terms, and a widening gap between earnings in Torres Strait and those on the mainland. After two years of feverish activity, the markets were glutted and shell was once again hard to find. The number of boats and men at work declined, then picked up, reaching a post-war peak in 1950-51, slumping in the next year, partially recovering in 1956-57, then falling away, this time for good. In 1960 an economist observed that the industry seemed less viable every year, ${ }^{42}$ and within a few months competition from plastics had dealt it a mortal blow.

Trends within the government fleet were similar to those in the private sector. During the boom it acquired forty boats, which the Islanders were quickly able to pay off from their wartime savings and postwar gratuities. But increasing stringencies forced one enterprise after another out of the race. The Island boats were left far behind when the master pearlers mechanized their fleet with engines and compressors. The government had to follow suit, but this meant a rise in running costs, so that more boats fell into debt. The government now adopted the policy of reducing its overall commitment and concentrating its boats in the hands of those who could run them most efficiently. By 1957 the fleet had dwindled to twenty-two, and by 1961 to fifteen, eight of them run by Badu's Nona company, which left some islands with no boat at all. By the mid-1960s the six Nona boats were the only ones still working.

All these changes had important implications for the communities, both social and economic. The government boats had always worked out from their home islands; now the masters' boats often did so. This

40 Reports for 1946-47.

41 Reports of the Royal Commission . . 1908:60.

42 Bach 1961:113.

94. 
meant supplies of dugong and turtle at the end of each working spell, which might be every four weeks if the work was mother-of-pearl. With $600-700 \mathrm{~kg}$ of meat to supplement the fish and crops produced by those who stayed ashore, the income from the subsistence sector was considerable. ${ }^{43}$ As Badu's fleet grew so did its subsistence production, but at the expense of other islands which became increasingly hard up.

There were other changes in the organization of work. When Island skippers took over the masters' boats they brought with them the traditional norms that had already been adapted to work on the government boats. Most of the latter were owned by family companies like the Nonas. If additional labour were needed, the skipper mobilized his own kinship and affinal connections. Master boat skippers recruited in the same way. Initially recruitment was mainly confined to the skipper's community, but as some communities lost their boats while Badu, specifically the Nonas, acquired more, it became necessary to recruit outside and even outside the kinship circle.

As I noted earlier, the Nona company came into being after the 1936 strike, when the government made over to them the big lugger, Wakaid, which had previously belonged to one of the tribes. There were nine brothers, all but one of working age, and several already experienced in skippering boats. They initially joined forces to work the Wakaid under Tanu but it was not long before the company expanded and they had boats of their own. The boats were lost during the war, but the company resumed work in 1946 with two new ones. Once again the Nona family, which now included grown up sons of the older brothers, began by working together, hiving off as new boats became available. However, the expansion was too slow for some, who left to work for master pearlers. Most members of the family had the chance to prove themselves as skippers, either in the government or the private sectors, and while some failed, five of the brothers and four among the rising generation won solid reputations. However, Tanu continued to get the largest catch.

The company's quick expansion may have aided its survival. Other family companies, on Badu and elsewhere, foundered on internal rivalries - 'everyone wanted to be boss'; whereas ambitious Nonas found an outlet before tensions reached danger point. Only the younger members worked under Tanu for any length of time, and even they sustained the hope of eventual advancement.

As well as skippering his own boat, Tanu acted as company head. $\mathrm{He}$ interfered little in the day-to-day routines of the other skippers,

43 Nietschmann (personal communication, 1977) found that a sample of forty-two dugong averaged $254.7 \mathrm{~kg}$ of butchered meat; a sample of fifty-four turtle averaged $131.1 \mathrm{~kg}$. Badu luggers regularly brought back one or two dugong and several turtles each month, and would go out for more if there was a feast. With eight luggers working, Badu was well supplied with meat. For further data on hunting, see Nietschmann 1976. 
but advised the government on how the money was to be allocated. The younger skippers, particularly, had little idea of how their earnings were computed. He also had a say in who should take charge of the boats. This was an area of considerable uncertainty, for the rights of company members remained undefined. In 1958 Tanu told me that he intended to divide the fleet among the branches of the family: one lugger to his most successful brother; one for two younger brothers; one to the family of a brother now dead. Three luggers belonged to him, but one of these should go to the family of his eldest brother, who had retired. This left out of account three brothers who were working for master pearlers, and who only benefited in the family's collective expenditures on weddings and memorials to the dead. They might, perhaps, have been accommodated in further expansion, but in the event there was no further expansion. Moreover, the family of the deceased brother failed to make a success of their venture and lost the boat to another branch. The son of Tanu's eldest brother resigned his command after some years, but was not replaced: the interest of this branch also lapsed. With the decline in pearling from the late 1960s, the number of Nona boats began to decline. After 1971 there were only two boats, skippered by two of Tanu's sons.

The company could run on in this uncertain manner because legally it was the government, not the Nonas, who owned the boats. In earlier reports the government spoke of Islanders working off the price of their boats, becoming in some sense owners, though still under government supervision. Later reports make no such reference, and it would seem that the government was the real owner, although Tanu played an important part in management and was well paid for his services.

The Nonas trained skippers both for their own boats and the pearling companies. Masters and officials took Tanu's recommendations seriously, and were not often disappointed. Badu skippers had a clear sense of authority, in sharp contrast to the indecisive leaders characteristic of other communities. Tanu's harsh regime of the 1930s remained their legendary charter, but it was no longer a direct model since few now worked trochus. Mother-of-pearl fishing required tight discipline while the divers were down, but not long hours of gruelling work or prolonged absence from home. Diving could only be done for a few hours each day, and for about three weeks in the month. Nevertheless, the 'hard work' ethic persisted: skippers left for the working grounds before the water was clear and stayed out until it was too dirty for diving. They stayed neither for church service nor festival. Anyone who showed signs of lingering was said to be tied to his wife's apron strings. These standards were ultimately sanctioned by financial incentives and the risk of losing one's boat. But they were also maintained by the competitiveness among skippers, which ensured that any falling short would be noticed and commented upon. The Nonas were particularly jealous 
of their family reputation and they all lived in fear of a rebuke from Tanu. The situation in Badu, with a dozen or more skippers at work, was quite different from that in other communities where there might only be one or two.

Throughout Torres Strait there was tension between skippers and their men, who always had some sense of being exploited. These feelings were not absent on the Badu boats, but were offset by other considerations. Divers, certainly, had something to gain by subscribing to the Nona regime. Skippers knew the value of a skilled man and showed appreciation in various ways. Although the Nonas generally preferred their own kinsmen, they did occasionally give other men recommendations that got them master boats. However, the divers' commitment was tempered by the realization that it was the Nonas, and not the ordinary Baduans, who gained most from their labours.

Ordinary crew enjoyed the camaraderie of boat life, but got little in the way of prestige or money, and they bore the brunt of the senior workers' tensions. Skippers had no hesitation in punching a youth who was disobedient, and occasionally threw someone overboard. It is worth noting that they were all big men! For these abuses there was no redress. The Island council was unsympathetic, being made up of Nonas; and the government referred complaints back to the council. Even parents might withhold support, for it was the custom for poorer families to ingratiate themselves with a skipper by sending a son to work under him. In return for this favour they could ask for a free passage to Thursday Island and expect generous shares of turtle and dugong caught by the boats on their way home from the working grounds. The old company boats had shared the meat out equally among the tribe; latterday skippers gave out meat or withheld it as they saw fit. A poor family, committed to a wedding or funerary feast, was wholly dependent on the generosity of a skipper for these festive foods.

The foregoing account is indicative of the changes taking place in Badu as a result of its commitment to pearling. The economic structure was also the power structure in a direct sense. An elected council would have found it hard to control the skippers, but in fact there had been no contest since 1947 when the government dismissed incumbents who were hostile to it and the Nonas. Thereafter, Tanu held office for life and secured the election of members of his family unopposed on his nomination.

The composition of the community, which now numbered about five hundred, had itself changed. There were relatively few people over forty, because many of the older generation had removed to Thursday Island, either to take up jobs ashore or get away from the Nonas, or because the Nonas had expelled them. But the skippers needed more young men than Badu could provide, and went recruiting around

97. 
neighbouring islands which no longer had boats of their own. The Nonas' kin ties with Saibai proved useful here, as did their affinal connections with several other communities. Those who became their regular associates and protégés soon settled on Badu, swelling the ranks of their supporters. To accommodate them the council abolished traditional land tenure, taking upon itself the right to allocate house and garden plots. ${ }^{44}$

The Nonas and their cronies became increasingly differentiated from the 'village people'. Their control of subsistence as well as cash production was reflected in their life style. They occupied spacious modern houses on high land, back from the village; and maintined large households that included poor relations and hangers-on who helped around the place and ran errands. The largest share of dugong and turtle meat went to them, and they maintained large gardens, worked by their boat crews during 'dirty water time'. With all these resources, their wedding and funerary feasts were the most lavish in Torres Strait.

Despite these changes, kinship remained the prevailing idiom of social relations. But people were also beginning to speak of 'skipper class' and 'crew class', and to regard the young Nonas as having better life chances. These young men were leaders among their peers and seemed to be able to get away with misdemeanours that would have landed the others in gaol. They married into the more important families in Torres Strait and showed a marked preference for wives with Pacific Island or Asian ancestry over 'Torres Strait natives'.

As the 'skipper class' rose in wealth and power, traditional forms of inter-dependence among ordinary Baduans dwindled in importance. Young people abandoned their parental homes for the more convivial and abundant households of their skippers, looking to them as marriage sponsors rather than their impoverished kinsfolk. The church, which had once provided the main source of prestige for older men, was now left to the women to run, with Tanu and a brother taking occasional major decisions. Religious festivals were still celebrated in the traditional way, but they were not always well attended and the dancing was often perfunctory. The real conviviality went on up at the big houses above the village, where one went only by invitation.

While Badu was becoming fully committed to pearling, reducing subsistence production to a subsidiary activity, other communities were continuing in the old way. They sent their young men to work on the Nonas' boats, or those of the white pearlers, and themselves stayed at home to make gardens and fish. Although now getting an additional income from Social Service benefits, their incomes were well below

44. It should be added that there was ample residential and gardening land. The change was made in order that those without hereditary rights should not be beholden to Baduan owners. See also Haddon 1904:284-291. 
what they had come to regard as their right as a result of the wartime experience. Even if they were to go to sea themselves, their earnings would not bring them appreciably closer to their goal. One heard such mutterings even in Badu, but the Nonas had a quick way with malcontents; elsewhere, however, protest was overt. To add to the problem, population was increasing while industry remained stagnant. The government expanded its building and welfare programs, providing work for some four hundred, but it could not expand indefinitely. ${ }^{45}$

The burgeoning economy and favourable labour market of northern Australia offered a safety valve for Torres Strait unemployment, but also posed a threat to the regional wage structure. Up to the outbreak of war, the government had confined Islanders to their reserves. After the war it allowed them to settle and work on Thursday Island, but the few available jobs were soon taken up and the demand for employment was nowhere near satisfied. In 1947 a small party of Islanders went south to cut cane. The experiment was a success and was repeated in subsequent years. At the end of each season, some of the cane cutters found other jobs and stayed behind. Presently their numbers were augmented by young Islanders who had absconded from trochus boats at North Queensland ports.

Although by 1960 there were probably no more than five hundred Islanders living on the mainland, their presence there had a profound effect on the situation in Torres Strait. They were mainly concentrated in railway fettling, an occupation unattractive to whites, but which did not have discriminatory rates for coloured workers. With overtime payments, a man could earn five and six times what he got at home, and the money was his to spend as he pleased, for the government did not extend its controls to the mainland. Islanders were soon in demand as first class tropical workers (a marked change from Torres Strait where they were always told they were lazy). News of life on the mainland filtered back, increasing the restlessness of pearling workers, and of government employees whose wages were geared to those in the industry.

Further emigration was obviously a solution to unemployment, but if not controlled it could also deprive the pearling industry and the government of their labour supply. The government solution was to delegate the decision to Island councils. Tanu was able to block emigration not only from Badu but from all the islands supplying him with labour, on the ground that Islanders were not yet ready to live without government protection.

45 Reports of the Chief Protector and of the Aboriginals' Department indicate that the Islander population rose from 2,368 in 1913 to 3,765 in 1938. In 1948 the stated figure was 5,000 and in 1960 7,250. Estimates by Caldwell, Duncan and Tait (1975), based on the Commoniwealth census, are considerably lower but record similar rates of growth. 
In 1960 , however, the industry suffered a permanent reverse. Plastics emerged as a cheaper competitor to shell in such fields as button manufacture. The trochus market collapsed and the demand for mother-ofpearl fell sharply. The industry was saved from extinction by the establishment of pearl culture stations, requiring supplies of live shell, but overall demand was still down and unlikely to expand. In 1960 eight government boats and five European-owned boats had worked out of Badu; in 1967 the numbers were six and two. With the population increasing, jobs declining, and mainland employers ready to fly Islanders to construction camps in the Northern Territory and Western Australia, it was no longer possible for councils to say no. Some Baduans settled on the mainland; others alternated spells home and away. But those at home could be more selective about whom they worked for. At the end of the year skippers could be seen treating their men to drinks in the hope of recruiting them again for the next season. It was said that one particularly rough skipper had been forced out because he could no longer get crew.

Now, in 1977, the demand for shell has fallen still further. There are three luggers still working, all commanded by Nonas, but employing New Guineans. Those Islanders who have not emigrated can find work in various State and Commonwealth government programs. A number of Baduans work on their own cray fishing, using Commonwealthfunded boats and freezers.

Nonas still control the Island council and they have a foothold in several government programs, but they are not the power that they were since they are no longer large-scale employers and no longer have much dugong or turtle to dispense. The people now go hunting in their own small boats. Most of the younger Nonas are working on the mainland, and among the surviving brothers there is discord over the undistributed assets of the family business. Tanu is the only one to have invested his savings (in Brisbane real estate), and it is assumed that he will pass this, along with whatever else remains, to his own sons. Now that he is getting old he is trying to secure his political office for a son, but the position is contested by a man of another family who has the backing of the village people and some of the Nonas as well.

In this paper I have analysed Torres Strait's relationship with Australia in terms of a model of internal colonialism, focussing on the articulation of subsistence and capitalistic modes of production. I have taken the marine industry as the dominant mode, supported by the subsistence sector, and I have represented the Queensland government as regulating the articulation. This is not to suggest that they were under unified control: each had its own institutional autonomy, but in the local setting the two meshed into one another. Government policy may not have been designed with the needs of the masters directly in view, but it 
tended to their advantage in the long run. And when the government itself became an entrepreneur, with the aim of making the communities self-supporting, their immediate interests converged.

The industry's primary need was for cheap labour, which it either imported or recruited locally. It could keep wages low because the populations from which it drew its labour could support themselves by subsistence activities. Queensland's segregation policy not only kept Islanders away from whites, but anchored them to communities where they could support themselves without money. ${ }^{46}$ There remained the problem of getting the Islanders to work regularly and at the required level of productivity, that is to behave like ordinary workers without neglecting their subsistence base. This was relatively easy in Badu where pearling and hunting could be combined, but difficult in agricultural Murray Island. Controlling both meat and money, Badu's skippers had a powerful base on which to consolidate their authority. Murray's split economy separated the men from the boys in a literal sense, leaving the skipper in the anomalous situation of being a man without a garden.

As Islanders took over the organization of pearling, first on the company boats, then on the masters' boats, the conflict between use and exchange values became blurred. Men worked to put their island ahead of the others, or to build churches. The skipper-crew relationship became a service between kin, masking the trend towards inequality. These conditions existed throughout the Strait, but the Nonas were particularly well placed to take advantage of them because of their ambiguous place in the community.

Around the turn of the century Islanders occupied an inferior position in the labour force, vis-a-vis Asians and Pacific Islanders as well as whites. With the elimination of foreign labour after 1945 they were able to become skippers and divers. However, almost all the top-notch skippers were part-Asian or Pacific Islanders, perhaps because the notion of foreigners being superior survived. This brought into existence a small elite who, like the Nonas, could earn as least as much as unskilled whites, and who enjoyed a much higher standard of living than other Islanders. Despite its class-like character, this elite was not an extension of mainland stratification but a colonial token, having no currency outside Torres Strait. Its control of capital was tenuous at law and effective only under the peculiar conditions prevailing within the region. Similarly, the control of labour, on which it was primarily dependent, was achieved through the manipulation of kinship and communal ties. It is significant that a sizeable part of the Nonas' wealth went in lavish wedding and funerary celebrations which validated their status among their own people, but not among whites. In short, the elite was more firmly

46 The development of the island community in the colonial conditions suggests at least a loose parallel with the closed corporate communities of Meso-America and Java (see Wolf 1957). 
tied to Torres Strait than humbler Islanders, and it quickly moved into alliance with the government when the colonial structure came under threat.

We have seen that the colonial regime came under severe strain after 1945, due to the rupturing of isolation, a revolutionary rise in expectations under conditions of stagnation, and a burgeoning population. The opening up of Thursday Island and of a new range of government jobs went only a short distance towards solving the problem; and boat companies, skippers and local government councils became increasingly subject to conflicting pressures. Cracks began to appear in the facade of kinship loyalty and communal solidarity.

The opening up of the mainland labour market provided a short term solution to the problems of unemployment, economic frustration and political disaffection, but at the cost of undermining the colonial system. Those who remained became increasingly unwilling to work for small wages, or to accept the discrimination between black and white workers. Once Torres Strait workers had made their name elsewhere, the colonial economy's need for a labour monopoly came into direct contradiction with the mainstream economy's need for a free labour flow.

Commonwealth Social Service benefits, such as child endowment and old age pensions, introduced a further complicating factor after 1943. In the agricultural eastem islands they relieved some men of the need to work on the boats. In the western islands they probably reduced the pressure for subsistence production. In the quasi-urban conditions on Thursday Island they complemented the inadequate wages of workers who could no longer grow crops, gather firewood or catch more than the occasional fish.

As in other parts of Australia, there was an increasing postwar inflow of special aid for indigenous people, in the form of housing, health and education facilities, and development projects. With the decline of the marine industry Torres Strait politics has increasingly focussed on the distribution of government funds, and the old pearling elite have been increasingly displaced by new men with better education and wider horizons. Anchored to their communities, the Nonas and others like them had little time for education or travel, and so are less well equipped to operate in the new conditions.

I do not think that the model of internal colonialism can be usefully applied to all indigenous people in Australia, but it would seem to be appropriate to the northern cattle industry which has long depended on cheap, seasonal Aboriginal labour. 'Station blacks' have continued to maintain themselves by hunting and gathering at certain seasons, and have retained much of their traditional way of life. One could expect the mustering camps and droving teams to offer parallels with the pearling boat crews. But the prevailing tendency, particularly in the Northern 
Territory, has been for the government to concentrate population in large settlements so that only a small proportion could either obtain employment or live off 'bush tucker'. With rising rural unemployment, in the south as well as the north, the obvious comparisons are with underdeveloped regions of Western Europe and North America, rather than with the internal colonies of South Africa or the Andean republics.

UNIVERSITY OF SYDNEY

\section{BIBLIOGRAPHY}

Austin, Tony. 'F. W. Walker and Papuan Industries Ltd.', Journal of the Papua and New Guinea Society, 6 (1), 1972:38-62.

Bach, John. 'The political economy of pearlshelling', Economic History Review, $14(1), 1961: 105-114$.

Beckett, Jeremy. 'Rivalry, competition and conflict among Christian Melanesians', in Hiatt, L. R. and C. Jayawardena eds. Anthropology in Oceania. Sydney, 1971:27-46.

'The Torres Strait Islanders', in. Walker, D. ed. Bridge and barrier: the natural and cultural history of Torres Strait. Canberra, 1972:307-326.

'Mission, church and sect: three types of religious commitment in the Torres Strait Islands', in Boutlier, J. A. et al eds. Mission, church and sect in Oceania. (forthcoming).

Bleakley, J. W. The Aborigines of Australia. Brisbane, 1961.

Caldwell, J. C., Helen Duncan and Maree Tait. The demographic report. (The Torres Strait Islanders, v. 4). Canberra, 1975.

Douglas, John. 'The islands and inhabitants of Torres Strait', Queensland Geographical Journal, n.s. 15, 1899-1900:25-40.

Evans, Gaynor. Thursday Island 1878-1914: a plural society. University of Queensland, B.A. (Hons) thesis, 1972.

Evans, Raymond, Kay Saunders and Kathryn Cronin. Exclusion, exploitation and extermination: race relations in colonial Queensland. Sydney, 1975.

Gonzalez Casanova, Pablo. 'Internal colonialism and national development', Studies in Comparative International Development, 1, 1965:27-37.

Haddon, A. C. ed. Reports of the Cambridge Anthropological Expedition to Torres Straits. Cambridge, 1904-1935. Vols. 1 (1935), 5 (1904), 6 (1908).

Hartwig, M. C. 'The theory of internal colonialism - the Australian case' [A.N.Z.A.A.S. paper, 1976], in Wheelwright, E. G. and K. Buckley eds. Essays in the political economy of capitalism. (forthcoming).

Hechter, Michael. Internal colonialism: the Celtic fringe in British national development 1536-1966. London, 1974.

London Missionary Society. Reports and Correspondence, New Guinea boxes. Microfilm, National Library of Australia, Canberra.

MacGillivray, John. Narrative of the voyage of H.M.S. Rattlesnake . . . London, 1852. 2v.

Nietschmann, Bernard. 'Torres Strait Island hunters and environment', (Seminar paper, Department of Human Geography, Australian National University, 1976).

Press, Irwin. 'Ambiguity and innovation: implications for the genesis of the culture broker', American Anthropologist, 71 (2), 1969:205-217.

Queensland Parliamentary Papers. 'Report of the Parliamentary Commission on the pearling industry', Queensland Parliamentary Papers, 1897.

'Report of the Royal Commission on the pearling and beche-de-mer industries', Queensland Parliamentary Papers, 1908.

Reports: Chief Protector of Aborigines; the Chief Protector's Department; the Aboriginals' Department; the Sub-Department of Native Affairs; Department of Aboriginal and Islander Affairs. Queensland Parliamentary Papers, passim. 
Rowley, C. D. The remote Aborigines. Canberra, 1971.

Somerset Magistrates' Letter Book, 1872-1877. Oxley Library, Brisbane. MS.

Stavenhagen, Rodolfo. 'Classes, colonialism and acculturation', Studies in Comparative International Development, 1, 1965:53-77.

Taussig, Michael. 'The genesis of capitalism amongst a South American peasantry: devil's labor and the baptism of money', Comparative Studies in Society and History, 19 (2), 1977:130-155.

Treadgold, M. L. The economy of the Torres Strait area: a social accounting study. (The Torres Strait Islanders, v. 2). Canberra, 1974.

Wolf, Eric. 'Closed corporate peasant communities in Meso-America and Central Java', Southwestern Journal of Anthropology, 13 (1), 1957:1-18.

Wolpe, Harold. 'The theory of internal colonialism: the South African case', in Oxal, Ivar, Tony Barnett and David Booth eds. Beyond the sociology of development.... London, 1975.

104. 